UDC 327(498)(437)(497.1)"1936/1937"

https://doi.org/10.22182/spm.6642019.1

Article received: 27.08.2019.

Accepted for publishing: 05.11.2019.

Original scientific paper
Serbian Political Thought

No. 4/2019, Year XXVI,

Vol. 66

pp. 05-23

Marusia Cîrstea*

University of Craiova - Faculty of Social Sciences, Romania

\title{
Romanian Prime Minister Gheorghe Tătărescu in the Capitals of the Little Entente: Belgrade (1936) and Prague (1937)
}

\section{Abstract}

The present article presents certain aspects of the relations between Romania, the Czech Republic and Yugoslavia in the interwar period. The fourth decade of the last century in particular was extremely rich in political, diplomatic and military events. Within this international context, Romanian Prime Minister Gheorghe Tătărescu (1934-1937) sought to establish bilateral contacts - with the great powers of Europe, but mainly with the members of the Little Entente - meant to both strengthen bilateral relations and clarify the states' perspective on the events in progress.

During his visits to Belgrade and Prague - as emerges from the press of the time - Gheorghe Tătărescu permanently advocated maintaining the status-quo and the political, economic and military cooperation between the states of the Little Entente.

Key words: the Little Entente, Gheorghe Tătărescu, Milan Hodža, Milan Stojadinović.

\footnotetext{
* Associate Professor cirsteamara@yahoo.com
} 


\section{Introduction}

Gheorghe Tătărescu was appointed Prime Minister of Romania on 5 January 1934 by King Carol II (Giurescu 2003: 428). He left his mark on the entire government activity in 1934-1937, promoting, on the economic plane, a policy of stimulation of the national industry; on the social plane, he supported the assertion of a middle-class group connected to the state; and on the foreign plane he sought to preserve the Versailles system, to promote regional alliances - the Little Entente and the Balkan Entente, to prevent both Germany and the Soviet Union from dominating south-eastern Europe (Chistol 2007).

Gheorghe Tătărescu's administration, performed in the name of the National Liberal Party, proved capable to "steer the stabilisation and re-launching of Romania's economy, the organic development of the national culture and society, the strengthening of Romania's international prestige through a coherent foreign policy, meant to contribute to the defence of European order." (Tătărescu 1996: XXV)

In the summer of 1936, acting on Nicolae Titulescu's suggestion, King Carol II and Prime Minister Gheorghe Tătărescu decided to devise a document outlining Romania's foreign policy. Thus, on 14 July 1936, the document was compiled, stipulating the following: the need to conclude a pact between France and the Little Entente against any aggressor; cessation of the attacks launched by the Romanian press against all foreign states; publication of articles in favour of a rapprochement to the USSR "indicating that we cannot preserve our current alliances with France, the Czechoslovakian Republic and Turkey if we do not reach an agreement, or even become an enemy of the USSR, the ally of our allies." (Scurtu 2003: 503; Popișteanu 1968: 177) Essentially, this document was meant to underline the following: how destructive was the division of continental security into western security and eastern security; the need to accomplish a unified system of security; the conclusion of regional politico-military pacts which would emphasise the necessary relation between local security, continental security and world security. (Potra 2007: 29-166) "In order to accomplish these permanent goals - emphasised Gheor- 
ghe Tătărescu - we strengthened our alliances and friendships, at the same time maintaining the best relations with all states indiscriminately. Our cooperation with the Czechoslovakian Republic and Yugoslavia within the framework of the Little Entente proved increasingly fertile for the destiny of our peoples and the life of this part of the world, where history placed us guardians." (Tătărescu 1996: 192) The government led by Gheorghe Tătărescu continued to promote the regional alliances - the Little Entente and the Balkan Entente - as means of preserving the Versailles system of peace agreements. At the same time, starting with 1934, meetings and consultations between the representatives of the Balkan states expanded. In the context of the existing international relations, Nicolae Titulescu's removal on 29 August 1936, from the Ministry of Foreign Affairs, translated as Romania's adjustment to the new realities, the search for new political and diplomatic measures and methods which would allow it to counteract the obvious danger to the security of the country's territorial status-quo, to its national independence, deriving from the failure of collective security, as a result of the open assertion of German revisionism and revanchist attitudes, the policy of appeasement followed by "the Western democracies" (France and England) and the American "isolationism”. (Dobrinescu, Pătroiu, Nicolescu 1999: 194) Tătărescu was aware that Nicolae Titulescu's replacement with Victor Antonescu, "a true traditionalist in our foreign policy," would be construed as "a new direction in the country's foreign policy" but, he added, this interpretation "would soon be invalidated by the government's future actions and attitudes." (Moisuc 2003: 246) Throughout his administration, Gheorghe Tătărescu's foreign policy observed the leitmotif of "extending alliances and establishing friendly relations with all peoples." (Tătărescu 1996: 232) In connection with the relations between the member states of the Little Entente, the Czechoslovakian Prime Minister Milan Hodža declared - following the June 1937 meeting on the Danube, on board the Carol II, attended by Stojadinović, Hodža, Tătărescu and Victor Antonescu: "The Little Entente becomes an indispensable tool in the consolidation of the Danube basin and, therefore, an instrument of world peace;" (Campus 1968: 286) while in October 1937 Victor Antonescu emphasised that "The international situation is, evidently, evolving. There has not been a remarkable event which would 
necessitate any change in the previously established decisions of the Little Entente. In Geneva we had permanent contact with the delegates of the Little Entente and the Balkan Entente [...] who convinced us that the policy followed so far does not require new decisions. The essential character of both the Little Entente and the Balkan Entente is the widest mutual trust; the two organisms build a unitary entity. It is essential that in all possible events the two organisms maintain an unwavering joint attitude." (AMAE, fund 71 Romania, vol. 3: 177-178)

To put into practice the "new direction," the Romanian Prime Minister Gheorghe Tătărescu made several official visits to Belgrade, Prague, Paris, London, among others.

\section{Foreign press on Gheorghe Tătărescu's visit to Belgrade}

In October 1936, Gheorghe Tătărescu made a private visit (unofficial, as the foreign press agencies claimed) to Belgrade in an attempt to "liquidate Titulescu's planned Romanian-Soviet alliance" (AMAE, fund Special Files, vol. 375/2: 13) - specified the Hungarian newspaper Nemzeti Újság. This thesis - maintaining the reality of "certain changes in Romania's foreign policy" - was also supported by the Polish newspaper Ilustrowany Kuryer Codzienny, which published a special telegram from Vienna - entitled "Romania and Yugoslavia moving away from the Soviets. The Czech Republic threatens isolation" - and which emphasised the following: "Prime Minister Tătărescu, who arrived in Belgrade yesterday [21 October 1936], brings King Carol II's approval of a complete change in Romania's policy towards the Soviets. In Belgrade the standards of Romania's and Yugoslavia's foreign policy will be established, in the sense of a reserved attitude towards Russia. This step is meant to present Czechoslovakia with an accomplished fact. If Czechoslovakia does not draw the correct conclusions, it will in future be completely isolated in its foreign policy, although it is a member of this agreement. The Romanian Prime Minister's visit to Belgrade is all the more important as it is made on the eve of King Carol's visit to Prague. According to different intelligence, during his stay in Prague, King Carol will inform President Beneš about the changes made in Romania's and Yugoslavia's foreign policy." (AMAE, fund Special Files, vol. 375/2: 15) 
Around Gheorghe Tătărescu's visits to Belgrade, the Danish press also "echoed certain news from an English and French source." ((AMAE, fund Special Files, vol. 375/2: 18) Thus, the Social-Demokraten made a synthesis of the contradictory news, emphasising that "the Tătărescu-Stojanović meeting would have something to do with the possible change in the traditional policy of Romania and the Little Entente, indicating this political organisation's concern to avoid any commitments that could draw it in a conflict with Germany. England's and France's ineffectuality at truly opposing Germany's arming, intended to lead to the Reich's hegemony in Europe soon, would clarify - the newspaper continued - Romania's and Yugoslavia's tendency to liberate themselves from the French alliance, in order to achieve a perfect neutrality. However, in relation to Mr. Krofta's categorical statements, it remains to be seen if these divergent attitudes could - in the Danish opinion - cause the break of the Little Entente." ((AMAE, fund Special Files, vol. 375/2: 18-19)

The Hungarian newspaper Budapesti Hírlap of 22 October 1936 mentioned that "Tătărascu will have political talks with the Prime Minster and the Foreign Minister Stojadinović," (AMAE, fund Special Files, vol. 375/2: 16) while the French newspaper L'Oeuvre reported that 'Prime Minister Tătărascu travelled to Belgrade to convey to the Yugoslavian Prime Minster the King's [Carol II's] approval of Romania's and Yugoslavia's new foreign policy, which displays great reserve towards Russia. In this way, they intend to present Beneš, the President of the Czechoslovakian Republic, with and accomplished fact." (AMAE, fund Special Files, vol. 375/2: 16-17)

The foreign press alluded to Nicolae Titulescu's removal from office (29 August 1936), as a result of the fact that he militated in favour of a pact of mutual assistance with the Soviet Union, reaching, in July 1936, the conclusion of a protocol with Maksim Litvinov (People's Commissary for Foreign Affairs of the Soviet Union). Nicolae Titulescu's removal from Gheorghe Tătărescu's government - emphasised N. Krestinski, Soviet minister to Bucharest - was due to the fact that "Titulescu is a great, great man, only not for Romania." (Bold, Ciupercă 2010: 127) Following Nicolae Titulescu's dismissal, the foreign office was assumed by Victor 
Antonescu, who insisted that Romania's foreign policy remained unchanged, because it was not the prerogative of one single person, but of the entire government, led by Gheorghe Tătărescu in agreement with King Carol II. On these lines - of continuity in the foreign policy - the foreign press also mentioned that "when Mr. Antonescu succeeded Mr. Titulescu, he was quick to deny any profound change; but those who are advised know that certain goals had been established: improving relations with Poland, the agreement with Italy, settling differences between Yugoslavia and Romania, preparing the ground for better cooperation with Germany and redressing the poor impression seemingly created in Great Britain by Mr. Titulescu's latest outburst at the Convention regarding the Straits in Montreux." (AMAE, fund 71 Anglia, vol. 39: 288) Moreover, in an interview given by Victor Antonescu to L'Intransigeant, of 5 October 1937, regarding Romania's foreign affairs, he emphasised that "Our friendship and our alliance with France are the basis of Romania's overall foreign policy. Romania also wants to intensify its alliance with the states of the Little Entente and the Balkan Entente and strengthen the one with Poland. Friendly relations with England will also be consolidated. We will develop our friendship with Italy and entertain friendly and good neighbourly relations with Russia; as regards Germany, we have sound economic relations with this country." (AMAE, fund 71 Romania, vol. 3: 175; Cîrstea 2012: 217-227)

\section{Romanian and Czechoslovakian interest in strengthening cooperation in all domains "politically, diplomatically, militarily and economically," as reflected by the foreign press}

In the tumult of the events that took place between 1936 and 1938, Romania remained completely faithful to its traditional policy. In order to convey a message of solidarity between the member states of the Little Entente, King Carol II made an official visit to Czechoslovakia (between 28 October and 1 November 1936), (Calafeteanu 2003: 297) entering the Czechoslovakian territory on 27 October and the state capital on 28 October "on the very day of Czechoslovakia's national celebration," (AMAE, fund 71 Romania, vol. 375/3: 13; Cîrstea, 2013: 392-404) and after "a 
three-day stay in Vienna, accompanied by President Beneš, he would leave for Brno, the capital of Moravia, and Bratislava, the capital of Slovakia." (AMAE, fund 71 Romania, vol. 375/3: 14) On this occasion, there were "several councils during which current political problems were debated in a spirit of perfect harmony and means of joint future action were decided." (AMAE, fund Czechoslovakia, vol. 40: 280)

Politically, the visit which King Carol II made in Prague proved that "the Little Entente, far from displaying inner frictions, balances a perfectly united front against the fluctuations of European politics." (AMAE, fund Czechoslovakia, vol. 40: 133) Moreover, the first speech held by the Czechoslovakian president emphasised "the complete agreement between the member states of the Little Entente" and that, although the prince regent of Yugoslavia was not in Prague, "we sense the presence of our friend Yugoslavia and I am certain that these relations will become even closer." (AMAE, fund 71 Romania, vol. 375/3: 21) The talks between the officials of the two countries' also covered the future of the Little Entente, "in the sense that - by enlarging the field of the mutual obligations arising from the fundamental pact and their alliance treaties - the three states should commit to defending each other concertedly and unreservedly against any attack from a neighbouring state, whether it is Italy, Germany or Soviet Russia." (AMAE, fund 71 Romania, vol. 375/3: 133)

This visit would be followed by another in the spring of 1937 , that of Prime Minister Gheorghe Tătărescu, "a new opportunity to assert the community of feelings and interests between the two peoples;" (AMAE, fund 71 Czechoslovakia, vol. 41: 93) therefore, his visit to Czechoslovakia (22-25 March 1937) began in the Královo tourist centre, where "the people overcrowding the platforms welcomed the Romanian Prime Minister with ovations. The railway station was decorated with Romanian and Czechoslovakian flags." (AMAE, fund 71 Czechoslovakia, vol. 41: 111) Gheorghe Tătărescu's first official meetings were with Prime Minister Milan Hodža, Foreign Minister Kamil Krofta and President Edvard Beneš. The cities of Prague, Plzeň and Brno were visited. Referring to the friendship between the two countries, "dating from before the war, from the time when, both oppressed by Hungarianism, they fought 
hard to defend their spiritual heritage and preserve their language, their traditions and their rights," (AMAE, fund 71 Czechoslovakia, vol. 41: 93) The newspaper L'Indepéndence Roumaine emphasised that: "The solidarity between Bucharest and Prague being absolute, for all possible reasons. The two countries' national freedom relies on the same treaty, which they are determined to put into practice until the last drop of their strength. They are equally preoccupied with safeguarding the existing European peace and order, with opposing revisionism, and preventing any change in the balance, which would only be the prelude of new and upsetting developments." (AMAE, fund 71 Czechoslovakia, vol. 41: 93)

During conferences with the Czechoslovakian officials "all areas of cooperation between the two states were examined, from a political, diplomatic, military and also commercial perspective, in all details." (AMAE, fund 71 Czechoslovakia, vol. 41: 112) Moreover, the representatives of the two states "ascertained that development was parallel in the two counties and they share a perfect unity of effort and goals, in relation to international rapports." (AMAE, fund 71 Czechoslovakia, vol. 41: 113) During the talks it was underlined that "in Europe there is no other union whose solidarity and inner strength corresponds with that of the Little Entente" (maintained Mr. Milan Hodža) and that "our union is a lifeline for each of us and for all of us collectively" (emphasised Mr. Tătărescu). (AMAE, fund 71 Czechoslovakia, vol. 41: 114) It was also highlighted that the two governments agreed that "a constructive policy in the Danube basin was the most appropriate means to employ in resolving Central Europe's problems with Germany and Italy unequivocally and, at the same time, one of those instruments in the absence of which European consolidation could not be achieved." (AMAE, fund 71 Czechoslovakia, vol. 41: 115)

The entire Czechoslovakian press covered the official visit of the Romanian prime minster, Gheorghe Tătărescu, in Czechoslovakia. Thus, the government-oriented newspaper Prager Presse published an editorial note with the following content: "Starting with the first moment when he stepped on Czechoslovakian soil, Prime Minister Gheorghe Tătărescu was the target of cordial and spontaneous manifestations on the part of public opinion in our country. The press called the tune on the eve; it was joined by the 
crowds come to all the railway stations along the route to greet our guest [...] Czechoslovakia understands this visit not only as the proof of the steadfast and indestructible friendship that joins out countries together, but also as evidence of the fact that we, the Romanians, the Yugoslavians and the Czechoslovakians, are determined to become even closer through mutual acquaintanceship." (AMAE, fund 71 Czechoslovakia, vol. 41: 93; http://dspace.bcucluj.ro/handle/123456789/81870) The policy of rapprochement of the three states was partly attributable to Prime Minister Tătărescu, - as the Pražské Noviny emphasised, - who "has run the destiny of Greater Romania with a firm hand for more than three years, a period which clearly represents a critical time in the international political life of Europe and of each country separately. One can say the head of the Romanian government is one of those European men of state who are responsible for peace and security in Europe and are fully aware of it. Mr. Tătărescu, who possesses so many remarkable qualities and who demonstrated numerous merits in all areas of political activity, is greeted warmly by the entire Czechoslovakian people." (AMAE, fund 71 Czechoslovakia, vol. 41: 111; http://dspace.bcucluj.ro/handle/123456789/81870)

The influential newspaper Národní Politika published an article penned by Mr. Borsky, which mentioned, among others, that "Czechoslovakia and Romania belong to the great coalition of peace and their rapports are dictated by the overall interests of the guardians of peace, which constitutes the healthiest foundation of any alliance of foreign policy, (AMAE, fund 71 Czechoslovakia, vol. 41: 111; http://dspace.bcucluj.ro/handle/123456789/81870) while under Dr. Schoferle's signature, the same newspaper wrote: "The visit of Prime Minister Tătărescu, who knows the art of wining affection and popularity, offers the Czechoslovakian public the opportunity to welcome a dear guest as warmly and sincerely as possible. Abroad, Mr. Tătărescu's visit to Prague will constitute new evidence of the solidarity within the Little Entente." (AMAE, fund 71 Czechoslovakia, vol. 41: 111; http://dspace.bcucluj.ro/handle/123456789/81870) The Právo Lidu, the Social Democrat publication, also emphasised that "Mr. Tătărescu's visit represents the best reply to the campaign led by a certain part of the foreign press against Czechoslovakia and against the Little Entente." (AMAE, 
fund 71 Czechoslovakia, vol. 41: 111; http://dspace.bcucluj.ro/ handle/123456789/81870) The České Slovo, the newspaper of the Czechoslovakian Socialist-Nationalist Party, also published an interesting article, which highlighted the significance attributed by the Czechoslovakian public opinion to the presence in Prague of the head of the Romanian government "In itself, the fact that the Romanian Prime Minister decided to come to us at this very moment is evidence that the Romanian-Czechoslovakian relations are completely unambiguous and that they have remained influenced by all the recent attempts to weaken them. Mr. Tătărescu's words were adequate proof that these relations are developing and deepening and that the Little Entente, as a concerted organ, truly is part of European order and peace. A further guarantee is provided by the fact that our countries are animated by shared ideals, among which Mr. Tătărescu revealed reliance on allies and loyalty to the League of Nations and to the idea of collective security. We are especially delighted with Mr. Tătărescu's affirmation of these last two instruments of European peace: building trust in the Little Entente and in the European community to which we all want to contribute. This is the reassuring role of Mr. Tătărescu's visit to Prague." (AMAE, fund 71 Czechoslovakia, vol. 41: 101-104) The Venkov, the publication of the Agrarian Republican Party, emphasised Mr. Tătărescu's remarkable qualities "as a publicist, an erudite, a playwright, an art critic and a true Romanian character, with an outstanding French education." (AMAE, fund 71 Czechoslovakia, vol. 41: 101-104; http://dspace.bcucluj.ro/handle/123456789/81870) The Národní Listy, the National-Democrat Party newspaper, wrote: "In Mr. Tătărescu are joined a talented man of state and a talented literate and speaker. Even before the war, Romania knew the inspired art critic Gh. Tătărescu, appreciated and admired the distinguished playwright Tătărescu and appreciated the resourceful journalist and publicist Gh. Tătărescu. Romania's political and economic consolidation, as well as the strengthening of the state unity, which contributed largely to the increase in the esteem and the confidence that Romania was shown by the international political life, are as many merits of this exceptionally energetic, tenacious and cautious man of state. In him, we greet a true friend of our people and our state. The goal of his strategy is closer unity of the Little Entente and especially of the Romanian-Czechoslovakian relations. This 
does not, however, preclude him from pursuing a purely Romanian policy." (AMAE, fund 71 Czechoslovakia, vol. 41: 111; http:// dspace.bcucluj.ro/handle/123456789/81870)

The Prager Tagblatt wrote, among others, that "Mr. Tătărescu's journey at the end of the winter complements the visit made by H.M. King Carol II to our state at the beginning of the winter. Of particular note is the fact that Romania's Prime Minister pays special attention to the economic ties between the two countries. As always, the solidarity of the Little Entente is again emphasised, which is firm enough to ensure unified action in important matters, but also flexible enough to allow each of the three states a certain degree of freedom." (AMAE, fund 71 Czechoslovakia, vol. 41: 105; http://dspace.bcucluj.ro/handle/123456789/81870) The same newspaper mentioned the various diplomatic plans which preoccupied European chancelleries. "The German project meant to replace the Pact of Locarno is considered unsatisfactory in Paris and London. In the last few days, the problem of Central and South-Eastern Europe has gained prominence. Austria's attitude towards the German-Italian axis on the one hand, on the other hand its attitude towards the other Danube basin states, Mr. Schuschnigg's visit to Budapest, the voices raised in Austria in favour of a rapprochement with Czechoslovakia, the rumours of closer cooperation between the block of the Rome states and the Little Entente, are all capable to lend great importance to the talks carried out in Prague. The two heads of government have the opportunity to evaluate all the issues raised by the present day." (AMAE, fund 71 Czechoslovakia, vol. 41: 105; http://dspace.bcucluj.ro/handle/123456789/81870)

The Bohemia noted in an editorial: "Last autumn, when H.M. King Carol II, accompanied by Grand Voievod Mihai and Foreign Minister Victor Antonescu returned the visit made by the President of the Czechoslovakian Rebublic, Prime Minister Gh. Tătărescu, the main counsellor of the Romanian Sovereign, was unable to attend H.M. the King to Prague. He is doing it now and is cordially welcomed by the government and the entire press of Czechoslovakia. The newspaper underlines the importance of this meeting following Mr. Victor Antonescu's recent visit to Ankara and on the eve of President Beneš's visit to Prince Regent Paul in Belgrade. The newspaper showed that although Mr. Tătărescu's 
visit is presented as an expression of courtesy, it nevertheless is of the most important political nature, given on the one hand the personality of the Romanian Prime Minster and, on the other, the international situation." (AMAE, fund 71 Czechoslovakia, vol. 41: 106; http://dspace.bcucluj.ro/handle/123456789/81870)

On 22 March, the press in Belgrade also recorded in newspapers such as the Vreme and the Politika, that: "the Romanian Prime Minister will have important appointments with the political leaders of Czechoslovakia and especially with the heads of the military industry and important factories of military industry will be visited, especially those in Plzeň and Brno." (http://dspace. bcucluj.ro/handle/123456789/81870)

\section{Commentaries of the Western press regarding the meetings of the two heads of state}

The French press, through Le Petit Parisien of 22 March, published a correspondence from Prague: "Mr. Tătărescu's visit to Prague, following the solemn reception of H.M. King Carol II last October, will not be a simple show of friendship, but, judging by the composition of the Romanian delegation itself and the programme of the journey in Czechoslovakia, will allow the settling of important economic and financial matters, especially those concerning the equipment of the Romanian army." (http:// dspace.bcucluj.ro/handle/123456789/81871) The 23 March issue of the Journal des Débats published an article on the visit made by Mr. Tătărescu to Prague, signed by Mr Albert Mousset: "This visit, said the newspaper, is part of a series of meetings and conferences during which the representatives of the two alliances, the Little Entente and the Balkan Entente, will attempt to conjugate their action in the face of a rapidly developing international situation. The warmth of Mr. Tătărescu's reception in Prague proves that nothing remains of the regrettable incident regarding the book written by the former minister to Bucharest, Mr. Jan Seba, an incident which was exploited by those who oppose the solidarity of the Little Entente and the Romanian-Czechoslovakian friendship. As a matter of fact, the talks in Prague not only constitute a solemn manifestation of solidarity, but they also target material goals, 
especially the motorisation of the Romanian army with the support of the Czechoslovakian industry, on the strength of the financial agreement concluded a few weeks ago." (http://dspace.bcucluj.ro/ handle/123456789/81871)

The 27 March issue of Le Temps published from its special correspondent in Prague the following: "Mr. Tătărescu dedicated a large portion of his time to visiting Czechoslovakian armament manufacturers, and especially those in Plzeň and Brno, which confirms, if conformation was still needed, the desire of the Little Entente states to dispose of well equipped and homogeneous armies; but it goes without saying that the current political issues were approached by Mr. Tătărescu and his various interlocutors, Messrs. Beneš, Hodža and Krofta. The frequently brandished idea, yet so far kept unsuccessful, of cooperation between the States of the Danube basin, from which naturally, neither Germany, nor Italy would be excluded, or, in other words, cooperation between the block of Rome and the Little Entente seems to be progressing sensibly." (http://dspace.bcucluj.ro/handle/123456789/81871)

The English press mentioned as well, in The Morning Post of 22 March: "Prime Minister Tatarescu's visit to Prague is connected with a vast plan to open new factories in Romania, branches of Czechoslovakian armament manufacturers, so that the Romanian army could be motorised in the shortest time." On the other hand, the newspaper determined that the Prime Minister's visit was interpreted in Prague "as indication that Romanian-Czechoslovakian relations are about to become even closer than before, due to their cooperation in matters of armament. On this occasion, it announces that after his return from Prague, Mr. Tătărescu is to go on an official visit to Ankara, and in May will receive in Bucharest the visit of the prime-ministers of Turkey, Czechoslovakia and Yugoslavia." (http://dspace.bcucluj.ro/handle/123456789/81871) The Yorkshire Post of 23 March wrote: "Recent reports, according to which Germany and Italy are interested in closer connections with Yugoslavia, pay special attention to the present talks. Messrs. Tătărescu and Hodža exchanged opinions about the political situation in the Danube basin as well." (http://dspace.bcucluj.ro/handle/123456789/81871) The Daily Telegraph of the same say was of the opinion that "all conversations move towards establishing 
measures to unify the system of armament of the Little Entente." (http://dspace.bcucluj.ro/handle/123456789/81871)

The Manchester Guardian of 25 March emphasised that "Mr. Tătărescu's visit to Prague draws everybody's attention because of the importance of its military, economic and political goals. [...] This visit was crowned with the greatest success, constituting a re-statement of the solidarity between Czechoslovakia and Romania, as well as of the friendly cooperation between the three states of the Little Entente." (http://dspace.bcucluj.ro/handle/123456789/81871) Announcing the departure from Prague of Prime Minister Tătărescu, The Times of 27 March said: "According to an official statement, the goal of Mr. Tătărescu's visit was - apart from talks on general political matters - extending commercial affairs between the two countries and a detailed plan for financing Czechoslovakian supplies for the Romanian army. Mr. Tătărescu's talks with Mr. Hodža and Mr. Krofta demonstrated the complete agreement between the two governments and the perfect unity of goals of the three member states of the Little Entente. Czechoslovakia and Romania look kindly on the Italian-Yugoslavian rapprochement as a contributing factor in the consolidation of peace in that part of Europe. The Little Entente wishes to cooperate with all the other countries in the Danube basin, but at the same time resolutely opposes the restoration of the Habsburgs." (http://dspace. bcucluj.ro/handle/123456789/81871)

The German press also commented on Prime Minister Gh. Tătăescu's visit to Prague, the visit of Foreign Minister V. Antonescu to Ankara, as well as the visit to Berlin of Mr. M. Constantinescu, the governor of the National Bank, and the visit to Warsaw of Dr. C. Angelescu, Minister of Public Instruction, regarded as "living demonstrations of the Romanian foreign policy." The newspapers mentioned the fact that this new activity corresponded to current requirements which the Romanian foreign policy was facing in relation with the new constellation and the new currents which can be noticed in European politics. The German press insisted mainly on the perceived political aspect of the visit made by Mr Tătărescu, the president of the Council of Ministers. Thus, the Frankfurter Zeitung of 19 March reported that "this visit is not only of economic nature and neither is it limited to matters 
of armament. The talks to be held are going to cover the entire complex of problems which interest the relations between the member states of the Little Entente between themselves and also each state's rapports with its neighbours." (http://dspace.bcucluj.ro/ handle/123456789/81871) At the same time, Deutsche Allemeine Zeitung of 23 March wrote: "Prime Minister Tătărescu's visit to Prague assumes a very distinctive character due to the fact that it includes the review of the armament factories in Czechoslovakia. And the time chosen for this visit clearly expresses its purpose: to show that there can be no weakening of the Romanian-Czech relations and to put an appropriate end to the embarrassing discussions occasioned by the publication of the book Russia and the Little Entente, written by Czechoslovakia's minister in Romania." (http://dspace.bcucluj.ro/handle/123456789/81871) The Breslauer Neueste Nachrichten of the same day also reported: "the visit of the Romanian head of government to Prague does not have an economic character, as it was implied. On the contrary, the fact that he is accompanied by General Glatz, the secretary general to the Ministry of War, commissioned to discuss matters relating to armament, shows that the military alliance between the states of the Little Entente, respectively the alliance between Romania and Czechoslovakia, will feature at the top of the agenda. The toasts given by Messrs. Hodža and Tătărescu indicated that the cooperation between the States of the Little Entente had turned into a function of a concerted regional organ, with unified goals and methods in its foreign policy, which will prove resolute in its determination to defend both peace and its own borders." (http://dspace.bcucluj. ro/handle/123456789/81871) On the same lines, the Kölnische Zeitung reported the following: "The presence of the Romania Prime Minister, Gh. Tătărescu, in Prague may be somewhat construed to some extent as a prelude to the Little Entente conference, planned to take place at the beginning of April in Belgrade [...] Both parties showed their willingness for more intensified cooperation which would increase the efficiency of the Little Entente." (http://dspace. bcucluj.ro/handle/123456789/81871)

The Belgian press was also interested in the relations between the member states of the Little Entente. Thus, L'indépendance Belge of 28 March informed: “The results of Mr. Tătărescu's visit to Prague refuted all rumours of a dissociation of the Little Entente. 
Mr. Benes's future visit to Belgrade will further emphasise the firm commitments between these states [...] There is no trouble in the Little Entente [...] Mr. Tătărescu, who was accompanied by General Glatz, undersecretary of state at the Ministry of National Defence, made prolonged visits to several industrial armament manufacturers. Within the General Staff of the Czechoslovakian army, a coordination bureau has operated for some time responsible with all military matters of the cooperation between Czechoslovakia, Romania and Yugoslavia. After this short visit of the Romanian man of state, there will be no delay in completing the rearmament programme of the Little Entente." (http://dspace.bcucluj.ro/handle/123456789/81871)

The Swiss press, through the newspaper called La Tribune de Genève of 30 March, saw in Mr. Tătărescu's visit to Prague "a prelude of the conference in Belgrade" and cited Mr. Hodža, "who desires close cooperation with the Danube states, which would finally allow an improvement in the relations with Germany and Italy [...] Mr. Stojadinović has declared that he is kept informed by the governments of the Little Entente in the matter of the treaty with Italy." (http://dspace.bcucluj.ro/handle/123456789/81871)

The American newspapers also published the correspondence from Prague regarding the visit of Prime Minister Tătărescu. Thus, The New York Times of 22 and 23 March attributed it "special significance, from the perspective of a unification of the armaments in the member states of the Little Entente." (http://dspace.bcucluj. ro/handle/123456789/81871)

\section{A few conclusions regarding the significance of the conferences between the two heads of states: Romania and Czechoslovakia}

The visit of Prime Minister Gheorghe Tătărescu in Prague represented, as emphasised by the newspaper Viitorul, "a new and joyful occasion to state the indissoluble bonds which unite us with Czechoslovakia, on the one hand, while on the other it showed once again that the Little Entente constitutes, in the perfect unity existing between Romania, Czechoslovakia and Yugoslavia, as well as the perfect understanding that animates it, the ideal expression of the 
most faultless, complete and definitive alliance [...] All the visits in the last months, the journey of H.M. the King to Czechoslovakia, the conferences between Messrs. Gh. Tătărescu, V. Antonescu and Stojadinović, the president the Yugoslavian Council, the meetings of the Little Entente and of the economic council, as well as the visit of the authorised representatives of the Czechoslovakian and Yugoslavian governments in Bucharest, etc. - were characterised by brilliant manifestations of warm, honest and brotherly friendship." (AMAE, fund 71 Czechoslovakia, vol. 41: 111)

On the occasion of this visit, several deliberations were held, regarding the international situation, the connections between the member states of the Little Entente and the bilateral relations between Romania and Czechoslovakia. On these lines, the Romanian Legation in Prague issued a document on 24 March 1937 (AMAE, fund 71 Czechoslovakia, vol. 41: 112-116) referring to the results of the talks between Gheorghe Tătărescu and Milan Hodža, which specified the following: "The conferences between Prime Ministers Tătărescu and Dr. Hodža, in which Foreign Minister Dr. Krofta also participated, concluded on 24 March. The goal of these conferences, aside from general political matters, was to engage in discussions relating to the extension of the political commercial basis. To that effect, a special agreement was signed, regarding two important standard items of production which take a very important place in the economic rapports of both countries. In addition, a complete and detailed agreement was concluded, concerning the financial aspect of the Czechoslovakian supplies for the Romanian army [...] All areas of cooperation between the two states were examined from a political, diplomatic, military and commercial perspective in all details. The presidents of both governments ascertained that the development of the two states runs parallel and there is an absolute unity of labour and aspiration between them, in relation to international affairs. (AMAE, fund 71 Czechoslovakia, vol. 41: 112, 113)

Referring to the cooperation between the states allied in the Little Entente, the said Report of the Romanian Legation emphasised the following: "The latest conference of the Balkan Entente proved that the cooperation between the member states of the Little Entente is consistent with the Balkan politics [...] An important 
part of the talks was devoted by both heads of Government to the relations between the states of the Danube River basin, emphasising that the Little Entente maintains with all its consistency its opposition to any attempt to restore the Habsburgs. Then, they ascertained the perfect identity of perspective of the two Governments on the political, economic and commercial situation in the Danube River basin. In agreement with Yugoslavia, an agreement which results from the talks which Prime Ministers Tătărescu and Hodža had with the president of the Yugoslavian government, Stojadinović, the Little Entente is capable and willing to intensify its rapports with the signatory states of the Rome Protocols and thus contribute to the foundation and the establishment of fair relations with all the Danube states. The Romanian and the Czechoslovakian governments acknowledge that a constructive policy in the Danube basin was the most appropriate means to employ in resolving Central Europe's problems with Germany and Italy unequivocally and, at the same time, one of those instruments in the absence of which European consolidation could not be achieved. The two governments therefore agree that the friendly relations between their countries as well as their contract clauses may provide a successful contribution to the establishment of a modus videndi in Europe on the basis of the above-mentioned principles." (AMAE, fund 71 Czechoslovakia, vol. 41: 114, 115)

\section{References:}

AMAE (The Archives of the Romanian Foreign Ministry, Bucharest), fund 71 Romania, vol. 3, 375/3; fund Special Files, vol. 375/2; fund 71 Anglia, vol. 39; fund Czechoslovakia, vol. 40,41 .

Bold, Em., Ciupercă, I. (2010) Europa în derivă (1918-1940). Din istoria relaţiilor internaţionale. Iaşi: Casa Editorială Demiurg Plus.

Calafeteanu, I. (coord.) (2003) Istoria politicii externe româneşti în date. Bucureşti: Editura Enciclopedică.

Campus, E. (1968) Mica Înțelegere. București: Editura Științifică. 
Chistol, A. (2007) România în anii guvernării liberale Gheorghe Tătărescu (1934-1937). Târgovişte: Editura Cetatea de Scaun.

Cîrstea, M. (2013) "Regele Carol al II-lea al României în vizită la Praga (1936)". In: Cîrstea, M., Damean, S.L. (eds.) Românii în istoria Europei. vol. I. Târgoviște: Editura Cetatea de Scaun. pp. 392-404.

Cîrstea, M. (2012) "Victor Antonescu şi politica externă a României în anii 1936-1937”. In: Ghițulescu, M., Dindirică, L. (eds.) Stat şi societate, vol. IV. Târgoviște: Editura Cetatea de Scaun. pp. 217-227.

Dobrinescu, V.F., Pătroiu, I., Nicolescu, Gh. (1999). Relaţii politico-diplomatice şi militare româno-italiene (1914-1947). Craiova: Editura INTACT.

Giurescu, Dinu C. (coord.) (2003) Istoria României în date. Bucureşti: Editura Enciclopedică.

Moisuc, V. (2003) Istoria relaţiilor internaţionale. Până la mijlocul secolului al XX-lea. Bucureşti: Editura Fundaţiei România de Mâine.

Popișteanu, C. (1968) România și Antanta Balcanică. București: Editura Politică.

Potra, George G. (ed.) (2007) Nicolae Titulescu. Opera politico-diplomatică 1 ianuarie 1937 - 31 decembrie 1937. Bucureşti: Fundaţia Europeană Titulescu.

Scurtu, I. (coord.) (2003) Istoria Românilor. vol. VIII. Bucureşti: Editura Enciclopedică.

Tătărescu, Gh. (1996) Mărturii pentru istorie. București: Editura Enciclopedică

http://dspace.bcucluj.ro/handle/123456789/81870

http://dspace.bcucluj.ro/handle/123456789/81871 